TIP Periodica Polytechnica

Transportation Engineering

42(1), pp. 77-83, 2014

DOI: $\underline{10.3311 / \text { PPtr. } 7250}$

http://www.pp.bme.hu/tr/article/view/7250

Creative Commons Attribution (i)

RESEARCH ARTICLE

\section{Foreign visitors from Visegrad countries with regard to road safety in Poland}

Dagmara Jankowska / Justyna Wacowska - Slezak / Joanna Zukowska

RECEIVED 6 November 2013; ACcepted 15 January 2014

\begin{abstract}
In the paper the authors present road safety situation in the Polish regions mostly visited by Czech, Slovakian and Hungarian tourists. These regions include Mazowieckie, Dolnoslaskie, Slaskie and Malopolskie voivodeships. After description of the regions and main touristic destinations for foreigners from Visegrad countries, a detailed road safety analysis performed for the period 2007-2012 is given. The paper ends with conclusions in which the authors underline the main road safety problems and recommend the steps that should be undertaken in order to improve the road safety level.
\end{abstract}

\section{Keywords \\ road safety $\cdot$ tourism $\cdot$ traffic accidents analysis}

\section{Introduction}

In 2004 Poland and other V4 countries - Czech Republic, Slovakia and Hungary - have entered the European Union (Gaal, Török, 2012). Starting from this moment the borders of these countries were opened automatically and the citizens were free to travel without any limits. This has influenced both the amount of touristic traffic, and the exposure to risk. The quality of Polish roads and road safety management system do not ensure safety level comparable with the West European one; the risk of being killed in traffic is still three times higher in Poland than in Great Britain, The Netherlands or even in Germany. Thus, there is a huge room for improvements. One of the possible ways of doing it is monitoring the safety on particular roads. From the EU or V4 countries perspective, the monitoring should be performed on transit roads - mainly used by foreign citizens - to asses the current situation and propose special countermeasures. This article aims to determine and present the main touristic destinations and transit roads which have been chosen by tourists coming from V4 countries to Poland. The road safety analysis with respect to foreign tourists will also be performed and conclusion drawn.

\section{Road Safety and Cross Border Tourism in Poland}

Poland as a transit country has the highest percentage of people entering and leaving Poland from East and West (mainly Germans, Ukrainians and Lithuanians). Representatives of V4 countries - Czech Republic, Slovakia and Hungary - are travelling mainly around the south border of Poland and to the capital of Poland - Warsaw.

Poland is divided into 16 administrative regions - voivodeships. The largest number of tourists coming from V4 countries to Poland were recorded in Malopolskie and Mazowieckie voivodeships (in 2010). These are the regions where two major cities of Poland - Warsaw and Cracow - are located. Tourists from Slovakia, Czech Republic and Hungary also visited Slaskie voivodeship.

Poland is mostly visited by Czechs ( 89557 visitors), followed by the tourists from Hungary (52708) and Slovakia (50928). 
The majority of tourists from the Czech Republic and Slovakia make short trips to Poland, usually lasting 1 day.

Tab. 1. The most popular regions in Poland visited by V4 countries inhabitants (Czech Republic, Slovakia and Hungary) in 2010.

\begin{tabular}{ccccccc}
\hline \multirow{2}{*}{ Regions } & \multicolumn{2}{c}{ Czech Republic } & \multicolumn{2}{c}{ Hungary } & \multicolumn{2}{c}{ Slovakia } \\
\cline { 2 - 7 } & $\begin{array}{c}\text { Nr. of } \\
\text { Guests }\end{array}$ & Dist. & $\begin{array}{c}\text { Nr. of } \\
\text { Guests }\end{array}$ & Dist. & $\begin{array}{c}\text { Nr. of } \\
\text { Guests }\end{array}$ & Dist. \\
\hline $\begin{array}{c}\text { Malopol- } \\
\text { skie }\end{array}$ & 17737 & $19,80 \%$ & 25300 & $48 \%$ & 18471 & $36,26 \%$ \\
$\begin{array}{c}\text { Mazo- } \\
\text { wieckie }\end{array}$ & 17734 & $19,80 \%$ & 8989 & $17,10 \%$ & 7184 & $14,10 \%$ \\
$\begin{array}{c}\text { Slaskie } \\
\text { TOTAL }\end{array}$ & 14233 & $15,89 \%$ & 5094 & $9,65 \%$ & 9260 & $18,18 \%$ \\
\hline
\end{tabular}

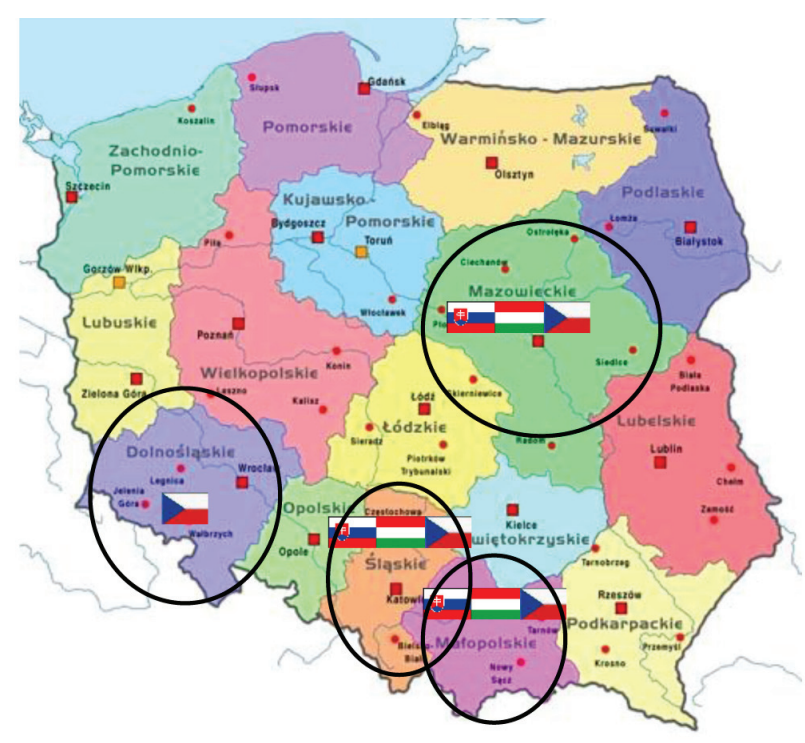

Fig. 1. Map of Poland and regions visited most by Czech, Slovakian and Hungarian tourists.

\section{Main touristic destinations in southern part of Poland}

Regions mostly visited by the tourist coming from the V4 countries:

- Mazowieckie voivodeship (Mazovia Region) - the largest region of Poland and the historical and contemporary centre of Poland. It covers the area of $35558 \mathrm{~km} 2$ and is home to 5178 480 people (13,6\% of the country population). Mazowieckie is one of the most dynamically developing regions in Poland and in Central-Eastern Europe. It connects the East and West of Europe. The most northern and southern parts of the continent are also connected via routes passing through Mazovia. Mazovia is also a home of many tourist attractions in Poland. It provides cultural attractions, as well as active tourism ones, including water tourism, riding, cycling and walking and business tourism. The main cultural centre of the region and the capital of Poland is Warsaw, which is home to dozens of theatres, National Philhar- monic, National Opera House, National Library and the National Museum. Warsaw has many magnificent historic buildings and monuments, including those in the Old Town (founded at the turn of the 14th century) and the New Town (begun in the 15th century), both of which were almost completely demolished during World War II but were restored and designated UNESCO World Heritage sites in 1980. Historical monuments in the region include the manor house in Zelazowa Wola, where composer Frederic Chopin was born and today it is transferred into Chopin Museum, and Plock with its Renaissance cathedral and many more. One third of Mazovia constitute green areas, among them Kampinos National Park (one of Poland's largest national parks), 9 landscape parks, 171 nature reserves and 62 protected landscape areas. This gives many possibilities for hiking, biking and horseback riding on numerous designated routes and thematic paths. There are also many regular events held in the region, such as knight tournaments at the castles, classical music concerts, folklore events in open-air museums, reconstructions of battles. Mazovia is also an attractive region for economic investment, not only due to its geographical location, but also to its role in the national economy (approx. 20\% of the national income is produced here). The main routes on which the V4 countries tourists arrive in the region include $\mathrm{K} 7, \mathrm{~K} 8$ and $\mathrm{A} 1$.

- Malopolskie voivodeship - it has an area of $15108 \mathrm{~km}^{2}$, and a population of 3267731 . The region is bordering with Slovakia to the south, and on the Polish regions of Slask to the west, Podkarpackie to the east and Swietokrzyskie to the north. It is an area with medieval towns and castles. A perfect place with great walks, hikes, skiing, biking, fishing, camping out in the open, etc. The voivodeship is bounded on the north by the Swietokrzyskie Mountains, on the west by Jura Krakowsko-Czestochowska (range of hills stretching from Krakow to Czestochowa) and on the south by the Tatra, Pieniny and Beskidy Mountains. Four national parks and numerous reserves have been established in the voivodeship. The region has areas for tourism and recreation, including Zakopane (Poland's most popular winter resort). The salt mine at Wieliczka, the pilgrimage town of Kalwaria Zebrzydowska, and Krakow's Old Town are ranked by UNESCO among the most precious sites of world heritage. At Wadowice, birthplace of Pope John Paul II there is a museum dedicated to the late Pope's childhood. The area of Oswiecim, with the former Nazi concentration camps Auschwitz-I and Auschwitz-II-Birkenau, is visited annually by million visitors. Another tourist destination is the town of Bochnia with its salt mine, the oldest in Europe. Malopolskie mineral-water and thermal springs together with bracing climate impacted the rise of many health resorts. Also agrotourism (tasting peasant life in comfort) proves even more popular. The roads used by the V4 inhabitants are: K7, 75,87, A4

- Slaskie voivodeship (Silesia region) - lies in the southern part of Poland, bordering from the south with Slovakia and Czech Republic, from the west with the Opolskie voivodeship, from the north with the Lodzkie voivodeship and from the east 
with the Malopolskie and Swietokrzyskie. It has an area of 12 $333 \mathrm{~km}^{2}$ and is populated by 4620624 inhabitants. Both northern and southern Silesia is surrounded by a green belt. Bielsko-Biala is enveloped by the Beskidy Mountains which are popular with winter sports fans, offering over 150 ski lifts and 200 kilometres of ski routes, equipped with artificial snow generators. Szczyrk, Brenna, Wisla, Korbielowo and Ustron are the most popular winter mountain resorts. Rock climbing sites can be found at Jura Krakowsko-Czestochowska. The ruins of castles forming the Eagle Nests Trail are famous attraction of the region. The Black Madonna's Jasna Gora Sanctuary in Czestochowa cannot be missed, it's the annual destination of over 4 million pilgrims from all over the world. South-western Silesia is popular for visiting parks, palaces and old monasteries (Rudy Raciborskie, Wodzisław Slaski). Along Odra river there are interesting natural reserve and at summer places for swimming. The Silesian region has a range of Poland's most diverse tourist attractions, including Castle Museum in Pszczyna and the Silesian Industrial Monuments Route - the only industrial tourism route in Poland, consisting of 31 facilities, which witnessed the industrial revolution and now function as tourist attractions. Particularly popular are Zywiec Brewery Museum, Tychy Brewing Museum and the "Guido" Ancient Hard Coal Mine in Zabrze. Silesia specialises in huge mass sports and cultural events at the Silesian Stadium, the Show and Sports Hall "Spodek", the Voivodeship Park of Culture and Recreation in Chorzow. Research carried out in 2009 reveals that in the last 12 months the Silesian Voivodeship was visited by $1,7 \mathrm{mln}$ tourists, 260,000 of which were foreign visitors. Short trips (2-4 days), mainly for work and business purposes, turn out to be the most popular. Roads which V4 tourists are using when travelling to Poland include A4, K1, 81 and 78.

- Dolnoslaskie voivodeship (Lower Silesia region) The region has an area of $19946 \mathrm{~km} 2$ and the population totalling 2914 362. Its capital and largest city is Wroclaw, on the Odra river, which is the most widely-visited. It is known worldwide for its festivals. The most important of them - Wratislavia Cantans - has been a meeting place for prominent international artists, conductors and orchestras for over 40 years, and the Lower Silesian Opera is known for the spectacular productions. Voivodeship is famous for its large number of castles and palaces. There are several hundred year old health resorts in Lower Silesia, closed down mines (i.e. gold mines) and underground factories built by the Nazis. The Sudety range (where a post office was located, the highest in Europe in the 19th century) is rich in mineral waters and semiprecious stones and is an important treasure of the Voivodship. Other highlights include Klodzko Fortress, Fort Silberberg, Wambierzyce, Legnickie Pole, Olesnica Mala, Lubiaz Abbey, Krzeszow, Henrykow, Vang stave church, Churches of Peace, Cave Bear, Museum of Gold Mining and Metallurgy in Zloty Stok, Coal Mine in Nowa Ruda, Museum of Industry and Railway in Jaworzyna Slaska, Museum of Papermaking in DusznikiZdroj, Skull Chapel in Czermna. The south part of the region is covered with mountains: Mount Sleza, Table Mountains, Owl Mountains, Karkonosze, The Main Trail Sudetes, Barycz Valley Landscape Park and connected with the history of World War II - complex tunnels Project Riese, a German Gross-Rosen concentration camp, German War Cemetery. The roads used in Lower Silesia by the V4 inhabitants are A4, K5, K3, 35.

\section{The patterns of V4 countries' visitors in Poland}

The visitors coming from V4 countries constitute a relatively small percentage of all tourists visiting Poland, in total only $4 \%$.

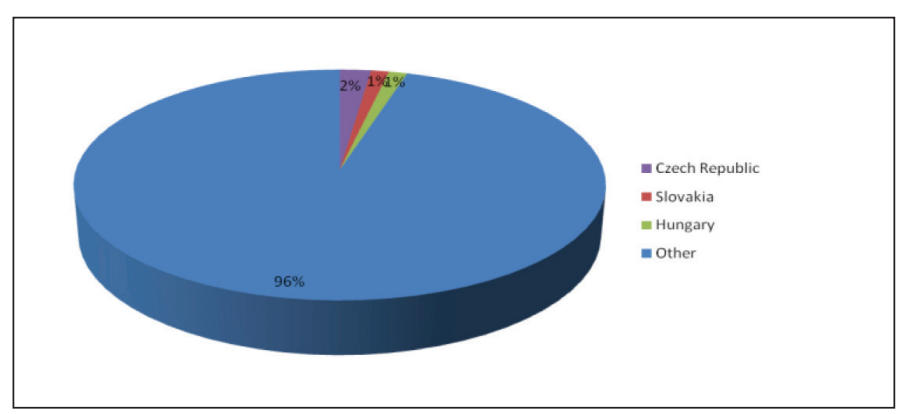

Fig. 2. Percentage of tourists from Czech Republic, Slovakia and Hungary visiting Poland in all tourists (2010).

Tourists from the Czech Republic most often come to Poland to visit Malopolskie, Mazowieckie and Slaskie voivodeships, but they also visit Dolnoslaskie with which they have a border. The number of Czech guests visiting different regions of the country are reflected in table 2 .

Tab. 2. Regions of Poland visited by Czech tourists (2010).

(Source: Tourism Institute; ** No. of guests (foreign tourists)/nights staying/spent at collective tourist accommodation establishments)

\begin{tabular}{|c|c|c|c|c|}
\hline Voivodeships & $\begin{array}{c}\text { Nr. of } \\
\text { Guests** }^{*}\end{array}$ & Dist. & $\begin{array}{c}\text { Nr. of } \\
\text { Guests }^{* *}\end{array}$ & Dist. \\
\hline Dolnośląskie & 10443 & $11,66 \%$ & 18959 & $10,38 \%$ \\
\hline Kujawsko-Pomorskie & 2169 & $2,42 \%$ & 4887 & $2,67 \%$ \\
\hline Lubelskie & 1230 & $1,37 \%$ & 2136 & $1,17 \%$ \\
\hline Lubuskie & 1672 & $1,86 \%$ & 3973 & $2,17 \%$ \\
\hline Lodzkie & 5076 & $5,66 \%$ & 13490 & $7,39 \%$ \\
\hline Malopolskie & 17737 & $19,80 \%$ & 31207 & $17,10 \%$ \\
\hline Mazowieckie & 17734 & $19,80 \%$ & 36726 & $20,12 \%$ \\
\hline Opolskie & 1512 & $1,68 \%$ & 2722 & $1,49 \%$ \\
\hline Podkarpackie & 2448 & $2,73 \%$ & 9648 & $5,28 \%$ \\
\hline Podlaskie & 1658 & $1,85 \%$ & 2694 & $1,47 \%$ \\
\hline Pomorskie & 2653 & $2,96 \%$ & 6736 & $3,69 \%$ \\
\hline Slaskie & 14233 & $15,89 \%$ & 26883 & $14,73 \%$ \\
\hline Swietokrzyskie & 1223 & $1,36 \%$ & 2437 & $1,33 \%$ \\
\hline $\begin{array}{c}\text { Warminsko- } \\
\text { Mazurskie }\end{array}$ & 940 & $1,05 \%$ & 2402 & $1,31 \%$ \\
\hline Wielkopolskie & 6435 & $7,18 \%$ & 11327 & $6,20 \%$ \\
\hline Zachodniopomorskie & 2394 & $2,67 \%$ & 6261 & $3,43 \%$ \\
\hline TOTAL & 89557 & $100 \%$ & 182488 & $100 \%$ \\
\hline
\end{tabular}


Table 3 shows the percentage of Czech tourists who visit Poland in all tourists coming to our country.

Tab. 3. Percentage of the Czech tourists and nights in the total number of tourists and nights in Poland (2010).

\begin{tabular}{cc}
\hline & $\%$ of total in PL \\
\hline Guests & $2,16 \%$ \\
Nights & $1,81 \%$ \\
\hline
\end{tabular}

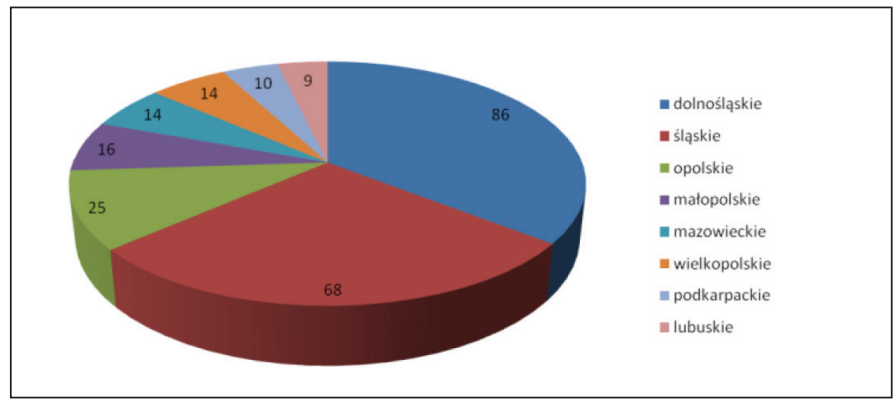

Fig. 3. Czech citizens killed and severely injured on Polish roads by voivodships in 2007-2012. (Source: SEWIK (Polish road accident database))

Czech citizens are mostly at risk in south part of Poland (Dolnoslaskie, Slaskie and Opolskie voivodeships).

In case of Slovakia, the situation is similar as with Czech tourists. The mostly visited regions include Malopolskie, Slaskie and Mazowieckie voivodeships. The number of Slovak guests visiting different regions of the country are reflected in table 4.

Tab. 4. Regions of Poland visited by Slovakian tourists (2010). (Source: Tourism Institute; **No. of guests (foreign tourists)/nights staying/spent at collective tourist accommodation establishments)

\begin{tabular}{ccccc}
\hline Voivodeships & $\begin{array}{c}\text { Nr. of } \\
\text { Guests }^{* *}\end{array}$ & Dist. & $\begin{array}{c}\text { Nr. of } \\
\text { Nights }\end{array}$ & Dist. \\
\hline Dolnośląskie & 2689 & $5,28 \%$ & 5052 & $4,34 \%$ \\
Kujawsko-Pomorskie & 615 & $1,20 \%$ & 1325 & $1,14 \%$ \\
Lubelskie & 605 & $1,19 \%$ & 1072 & $0,92 \%$ \\
Lubuskie & 586 & $1,16 \%$ & 1862 & $1,60 \%$ \\
Lodzkie & 2682 & $5,26 \%$ & 7162 & $6,16 \%$ \\
Malopolskie & 18471 & $36,26 \%$ & 32343 & $27,82 \%$ \\
Mazowieckie & 7184 & $14,10 \%$ & 16733 & $14,39 \%$ \\
Opolskie & 660 & $1,29 \%$ & 1381 & $1,18 \%$ \\
Podkarpackie & 2427 & $4,77 \%$ & 5346 & $4,59 \%$ \\
Podlaskie & 607 & $1,19 \%$ & 843 & $0,73 \%$ \\
Pomorskie & 1075 & $2,11 \%$ & 2549 & $2,19 \%$ \\
Slaskie & 9260 & $18,18 \%$ & 30740 & $26,45 \%$ \\
Swietokrzyskie & 506 & $1,00 \%$ & 1016 & $0,88 \%$ \\
Warminsko- & 410 & $0,80 \%$ & 1031 & $0,89 \%$ \\
Mazurskie & & $5,12 \%$ & 6697 & $5,77 \%$ \\
Wielkopolskie & 2607 & $1,09 \%$ & 1104 & $0,95 \%$ \\
Zachodniopomorskie & 544 & $100 \%$ & 116256 & $100 \%$ \\
\hline TOTAL & 50928 & & & \\
\hline
\end{tabular}

Table 5 shows the percentage of Slovak tourists who visit Poland in all tourists coming to our country.

Tab. 5. Percentage of the Slovakian tourists and nights in the total number of tourists and nights in Poland (2010).

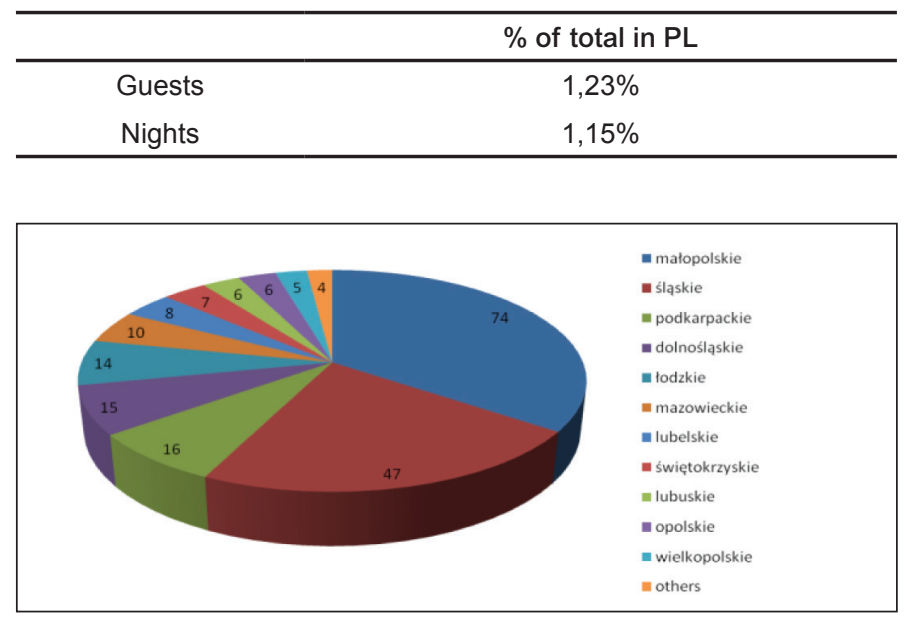

Fig. 4. Slovak citizens killed and severely injured on Polish roads by voivodships in 2007-2012. (Source: SEWIK (Polish road accident database))

Slovak citizens are mostly at risk in south part of Poland (Malopolskie, Slaskie, Podkarpackie, Dolnoslaskie).

Tourists from Hungary also visit Malopolskie, Mazowieckie and Slaskie voivodeships, with the first one being the mostly visited by them. The number of Hungarian guests visiting different regions of the country are reflected in tab. 6 .

Tab. 6. Regions of Poland visited by Hungarian tourists (2010).

(Source: Tourism Institute; ** No. of guests (foreign tourists)/nights staying/spent at collective tourist accommodation establishments)

\begin{tabular}{|c|c|c|c|c|}
\hline Voivodeships & $\begin{array}{c}\text { Nr. of } \\
\text { Guests }^{* *}\end{array}$ & Dist. & $\begin{array}{l}\text { Nr. of } \\
\text { Nights }\end{array}$ & Dist. \\
\hline Dolnośląskie & 2376 & $4,51 \%$ & 4178 & $4 \%$ \\
\hline Kujawsko-Pomorskie & 684 & $1,30 \%$ & 2022 & $1,84 \%$ \\
\hline Lubelskie & 943 & $1,79 \%$ & 1216 & $1,11 \%$ \\
\hline Lubuskie & 265 & $0,50 \%$ & 491 & $0,44 \%$ \\
\hline Lodzkie & 1668 & $3,16 \%$ & 3217 & $2,93 \%$ \\
\hline Malopolskie & 25300 & $48 \%$ & 55911 & $50,97 \%$ \\
\hline Mazowieckie & 8989 & $17,10 \%$ & 15192 & $13,85 \%$ \\
\hline Opolskie & 497 & $0,94 \%$ & 1045 & $0,95 \%$ \\
\hline Podkarpackie & 1255 & $2,38 \%$ & 2387 & $2,17 \%$ \\
\hline Podlaskie & 703 & $1,33 \%$ & 1370 & $1,25 \%$ \\
\hline Pomorskie & 1248 & $2,37 \%$ & 3753 & $3,42 \%$ \\
\hline Slaskie & 5094 & $9,65 \%$ & 10132 & $9,23 \%$ \\
\hline Swietokrzyskie & 405 & $0,76 \%$ & 769 & $0,70 \%$ \\
\hline $\begin{array}{c}\text { Warminsko- } \\
\text { Mazurskie }\end{array}$ & 356 & $0,67 \%$ & 1137 & $1,03 \%$ \\
\hline Wielkopolskie & 2366 & $4,48 \%$ & 5411 & $4,93 \%$ \\
\hline Zachodniopomorskie & 559 & $1,06 \%$ & 1470 & $1,34 \%$ \\
\hline TOTAL & 52708 & $100 \%$ & 109701 & $100 \%$ \\
\hline
\end{tabular}


Tab. 7 shows the percentage of Hungarian tourists who visit Poland in all tourists coming to our country.

Tab. 7. Percentage of the Hungarian tourists and nights in the total number of tourists and nights in Poland (2010).

\begin{tabular}{cc}
\hline & $\%$ of total in PL \\
\hline Guests & $1,27 \%$ \\
Nights & $1,09 \%$ \\
\hline
\end{tabular}

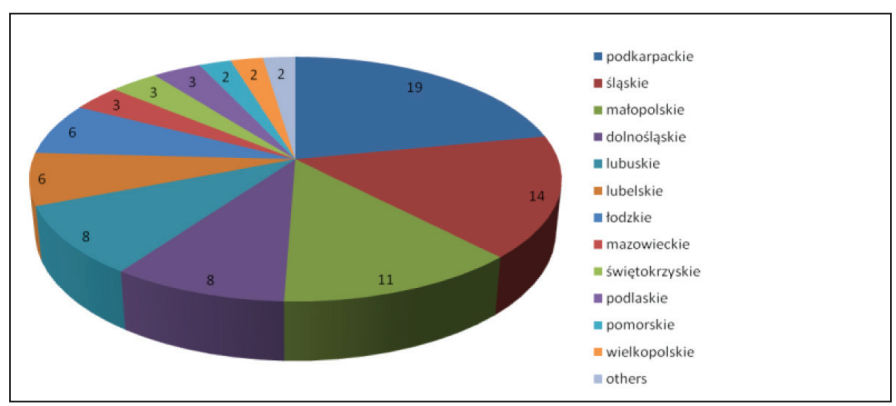

Fig. 5. Hungarian citizens killed and severely injured on Polish roads by voivodships in 2007-2012. (Source: SEWIK (Polish road accident database))

Hungarian citizens are mostly at risk in south part of Poland (Podkarpackie, Slaskie, Malopolskie, Dolnoslaskie voivodship).

Although Polish roads are not the safest in Europe, foreigners - especially from V4 countries - are not at big risk in our country. In years 2007 - 2012, in 819 accidents 130 people from V4 countries were killed and 830 were injured on Polish roads. It makes up $0,3 \%$ of all accidents which occurred in Poland in this period of time, $0,4 \%$ of all killed and $0,2 \%$ of all injured.

The most accidents involved Czech inhabitants, they were also injured and killed at the most, while Hungarians at the least.

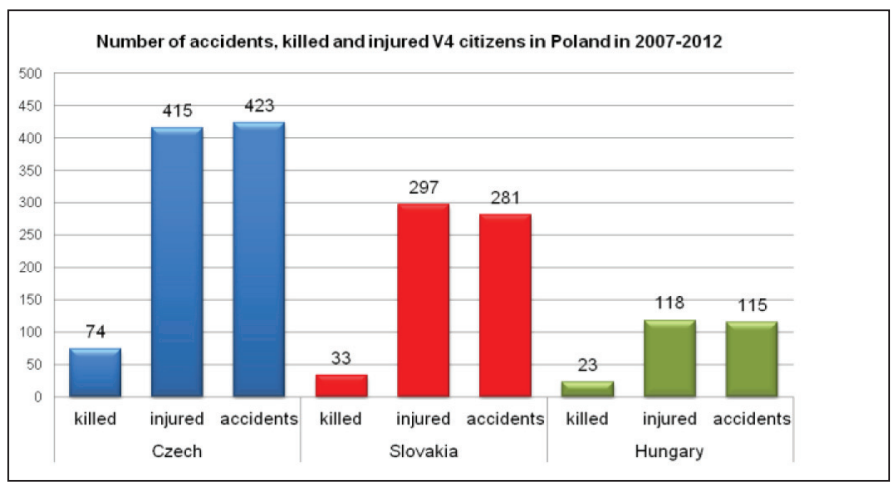

Fig. 6. Number of accidents, killed and injured V4 citizens in Poland 2007-2012. (Source: SEWIK (Polish road accident database))

\section{The road accident risk influencing V4 tourists in Poland}

There is no distinctions in Polish statistics between foreign people (i.e. professional drivers in transit) and tourists. We consider all tourists as foreign people.
The following table shows the numbers of accidents, collisions, killed and injured by countries, including the V4 representatives.

Tab. 8. Accidents caused by foreigners in PL (2011).

\begin{tabular}{ccccc}
\hline Country & Accidents & Killed & Injured & Collisions \\
\hline Germany & 77 & 8 & 101 & 1224 \\
Ukraine & 58 & 13 & 93 & 1158 \\
Lithuania & 48 & 10 & 63 & 933 \\
Belarus & 39 & 2 & 63 & 787 \\
Czech & 28 & 4 & 39 & 565 \\
Russia & 16 & 2 & 30 & 368 \\
Slovakia & 20 & 2 & 35 & 355 \\
Romania & 10 & 1 & 14 & 212 \\
Bulgaria & 10 & - & 16 & 197 \\
Hungary & 11 & 1 & 18 & 118 \\
\hline
\end{tabular}

Most of the accidents in 2011 were caused by the Germans (77 - 24\%), Ukrainians $(58-18 \%)$ and Lithuanians (48 $15 \%)$. This is due to the fact that Poland is a transit country and the highest percentage of people entering and leaving Poland are our neighbours, especially from East and West.

Czech people caused 28 accidents $(8,8 \%)$, in which 4 persons were killed and 39 injured. Slovak - 20 accidents $(6,3 \%)$, in which 2 - killed, 35 - injured. Hungarian - 11 accidents $(3,5 \%)$, in which 1 - killed and 18 injured. Czechs caused 565 traffic collisions, Slovaks - 355 and Hungarians - 118 .

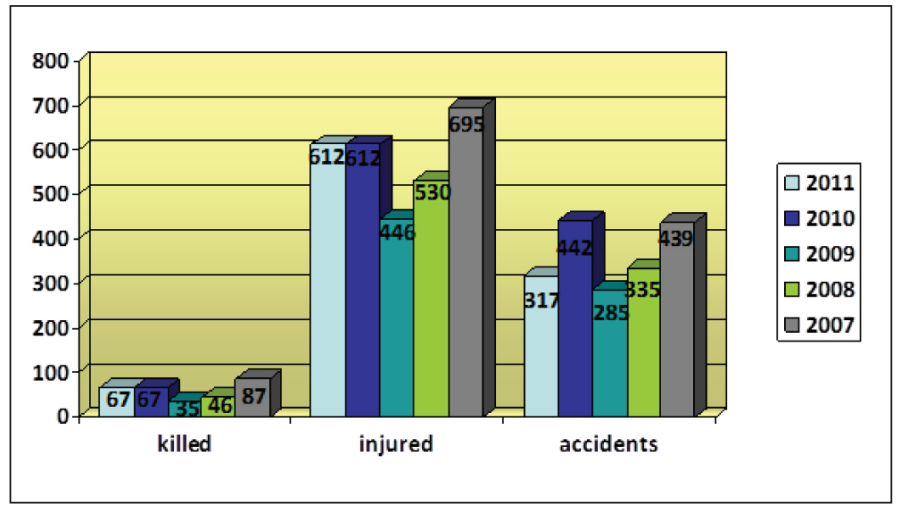

Fig. 7. Foreigners in Poland 2007-2011.

(Source: SEWIK (Polish road accident database))

The figure above presents all killed and injured foreigners, as well as the number of accidents with their involvement.

Main causes of the traffic accidents involving foreign people are:

- not adjusting the speed to traffic conditions,

- fail to yield the right of way,

- not keeping safe distance between vehicles,

- fatigue, sleepiness,

- inappropriate overtaking,

- inappropriate behavior towards pedestrian. 


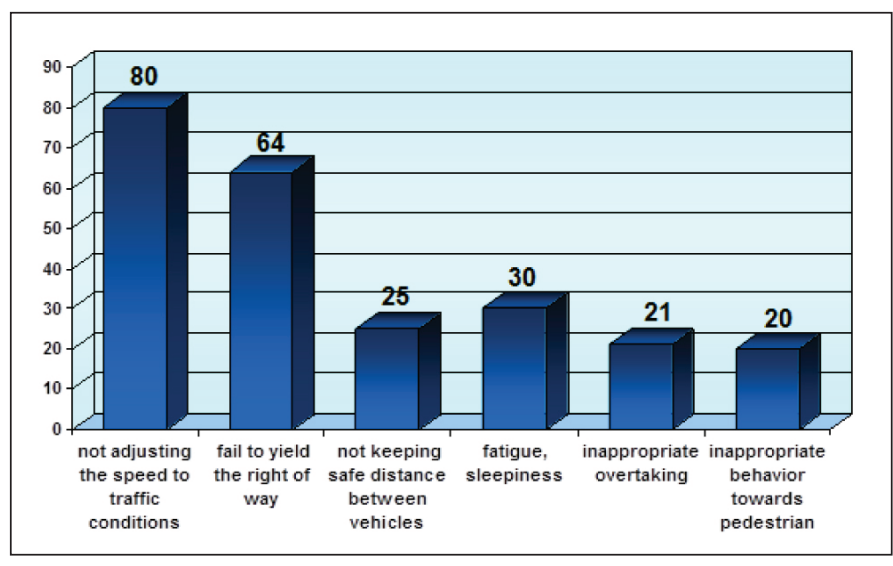

Fig. 8. Main accidents causes involving foreigners in 2011. (Source: SEWIK (Polish road accident database))

The accidents involving fatalities of V4 inhabitants are located on the following routes:

- National road 8 (K8) - connecting Kudowa Zdroj (border with Czech Rep.) and Warsaw (Mazowieckie voivodeship),

- National road 1 (K1) - leading from Cieszyn (border with Czech Rep.) to Lodz from where there is a connection to Warsaw (Mazowieckie voivodeship),

- National road 7 (K7) - connecting Chyzne (border with Slovakia) and Warsaw,

- National road 5 (K5) - leading from Lubawka (border with Czech Rep.) to Wroclaw,

- National road 19 (K19) - connecting Podkarpackie (border with Slovakia) and Mazowieckie voivodeships via Lubelskie,

- National road 46 (K46) - road originating in Kłodzko in Dolnośląskie voivodeship leading through Opolskie to Slaskie,

- Motorway A4 - connecting the southern voivodeships of Poland (also of interest for V4 - Dolnoslaskie, Opolskie, Slaskie and Malopolskie).

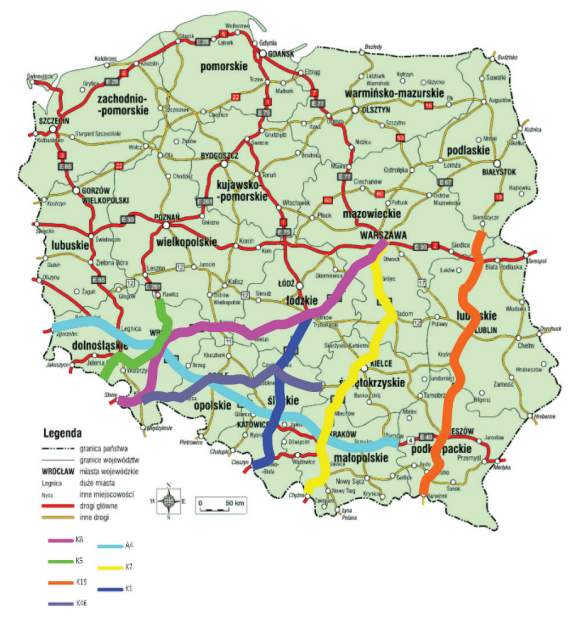

Fig. 9. Map of Poland with location of roads on which the V4 inhabitants are at biggest risk.

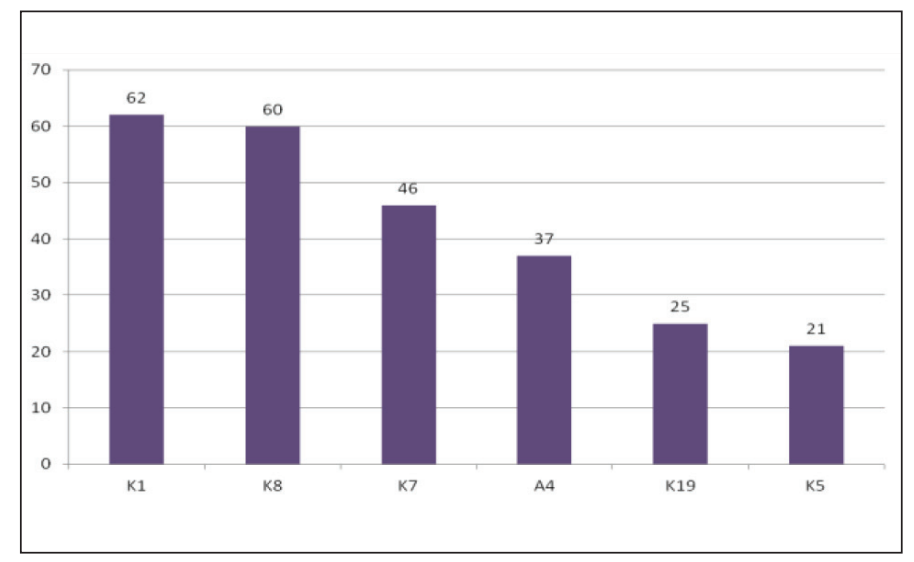

Fig. 10. Foreigners from V4 countries killed and severely injured in Poland by roads in 2007-2012. (Source: SEWIK (Polish road accident database))

Citizens from V4 countries are at risk on national roads $\mathrm{K} 1$, K8, K7 and motorway A4.

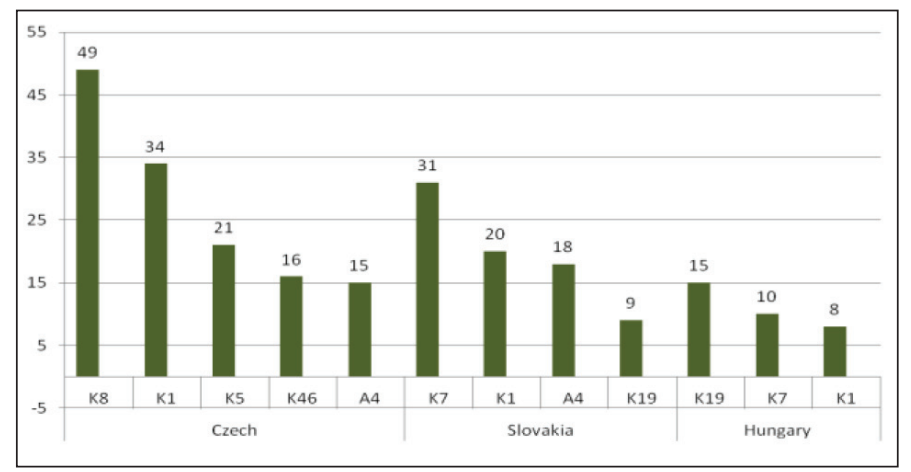

Fig. 11. Foreigners from three V4 countries killed and severely injured in Poland by roads in 2007-2012. (Source: SEWIK (Polish road accident database))

Tab. 9. Characteristics of the selected roads in Poland with regard to V4 inhabitants. Foreigners from three V4 countries killed and severely injured in Poland by roads in 2007-2012.

\begin{tabular}{|c|c|c|c|}
\hline $\begin{array}{c}\text { Roads to access touristic } \\
\text { regions }\end{array}$ & $\begin{array}{l}\text { Nr. of } \\
\text { personal } \\
\text { injury } \\
\text { accidents } \\
\text { in } 2010\end{array}$ & $\begin{array}{l}\text { Length } \\
\text { of route } \\
\text { [km] }\end{array}$ & $\begin{array}{c}\text { Traffic } \\
\text { in } 2010 \\
\text { [vehicle/day] }\end{array}$ \\
\hline $\begin{array}{l}\text { A4 (Dolnoslaskie, Opolskie, } \\
\text { Slaskie, Malopolskie) }\end{array}$ & 6 & 444,8 & 28948 \\
\hline K1 (Slaskie, Lodzkie) & 19 & 335,6 & 25759,26 \\
\hline K5 (Dolnoslaskie) & 2 & 133,2 & 8739,41 \\
\hline $\begin{array}{c}\text { K7 (Malopolskie, } \\
\text { Swietokrzyskie, Mazowieckie) }\end{array}$ & 7 & 505,6 & 19276,26 \\
\hline $\begin{array}{c}\text { K8 (Dolnoslaskie, Wielkopol- } \\
\text { skie, Lodzkie, Mazowieckie) }\end{array}$ & 8 & 527 & 17957,31 \\
\hline $\begin{array}{c}\text { K19 (Podkarpackie, Lubelskie, } \\
\text { Mazowieckie) }\end{array}$ & 5 & 445,2 & 8193,59 \\
\hline $\begin{array}{c}\text { K46 (Dolnoslaskie, Opolskie, } \\
\text { Slaskie) }\end{array}$ & 3 & 244,2 & 7849,72 \\
\hline TOTAL & 50 & & \\
\hline
\end{tabular}




\section{Conclusions}

Starting from 2004, the accession of Poland and other V4 countries - Czech Republic, Slovakia and Hungary - to the European Union, the borders of these countries opened automatically and the citizens were able to travel without any limits. Nevertheless, after almost 20 years the visitors coming from V4 countries constitute a relatively small percentage of all tourists visiting Poland, in total only $4 \%$. Those who come to Poland mainly visit the regions of Mazowieckie voivodship (Mazovia Region), Malopolskie voivodship, Slaskie voivodship (Silesia region) and Dolnoslaskie voivodship (Lower Silesia region). The first one is located in the central part of the country, the rest - in south of Poland. Although Polish roads are far from the safest in Europe, foreigners - especially from V4 countries - are not at big risk in our country. In years 2007-2012, in 819 accidents 130 people from V4 countries were killed and 830 were injured on Polish roads. It makes up $0,3 \%$ of all accidents which occurred in Poland during this time, $0,4 \%$ of all killed and $0,2 \%$ of all injured. Most often in those accidents were involved Czech inhabitants, while the Hungarians the least. The detailed knowledge of the nature and circumstances related to those accidents would be helpful in drawing conclusions and recommendations of the possible ways of safety improvement of particular groups of tourists (nations).

\section{Acknowledgements}

The issues presented in this article are the outcome of the project titled: "Intensifying PROfeSsionAl collaboration For safEr road transportation among the Visegrad countries (PRO-SAFE)", developed by a consortium of V4 countries and led by KTI Institute for Transport Sciences.

\section{References}

1 Gaal G., Török Á., Political effect on Major Transport Elements of Budapest after the Transition. Transactions on Transport Sciences, 5 (3), 127-136 (2012). DOI: $10.2478 / \mathrm{v} 10158-012-0015-2$

2 Jankowska D., Wacowska-Slezak J., Projekt SOL - Ocena sytuacji bezpieczeństwa ruchu drogowego $w$ regionach - badania opinii społecznej. Kwartalnik BRD, (2), 8-11 (2011).

3 Jankowska D., Mikušová M., Wacowska-Ślęzak J., Road safety problems in Poland and Slovakia - results of public opinion survey. Technika Transportu Szynowego, (9), 3223-3230 (2012).

4 Jankowska D., Wacowska-Slezak J., Road safety situation in the V4 countries, related to foreigners - Poland. In PRO-SAFE Conference, Warsaw 8.03.2013. (2013).

5 Jankowska D., Wacowska-Slezak J., Zukowska J., Piskorz K., The most popular touristic targets for Czech, Slovakian and Hungarian tourists in Poland vs. road safety. In PRO-SAFE Conference, Budapest 12.07.2013. (2013).
6 Jankowska D., Wacowska-Slezak J., Road safety and cross border tourism in Poland. In PRO-SAFE Conference, Zilina 05.12.2013. (2013).

7 Komenda Główna Policji, Wypadki drogowe w Polsce w 2012. Instytut Transportu Samochodowego, Warszawa (2013).

8 Polish Tourism Institute, Foreigners in accommodation base in Poland in 2010. Tourism Institute, Warsaw (2013).

9 SEWIK, Polish road accident database. Police Headquarter, Warsaw, (2012).

10 Zukowska J., An assessment of transport safety in Poland. An integrated system of transport safety - synthesis. Published in co-edition by Wydawnictwa Komunikacji i Łączności and Instytut Transportu Samochodowego, 42-56 (2012).

11 Zukowska, J., Innowacyjne narzędzia zarządzania bezpieczeństwem transportu drogowego na poziomie regionalnym. Autobusy. Technika, Eksploatacja, Systemy Transportowe, 14 (3), 2293-2303 (2013). 